\title{
バイアス電流導入型高周波グロー放電プラズマにおける クロムの発光線の励起挙動
}

\author{
児玉 憲治 $^{\circledR 1}$, 我妻 和明 ${ }^{1}$
}

\section{Excitation behavior of chromium emission lines from a radio-frequency glow discharge plasma associated with bias-current introduction}

\author{
Kenji KodAma $^{1}$ and Kazuaki Wagatsuma ${ }^{1}$
}

\author{
${ }^{1}$ Institute for Materials Research, Tohoku University, 2 - 1 - 1, Katahira, Sendai-shi, Miyagi 980 - 8577
}

(Received 7 May 2004, Accepted 16 September 2004)

\begin{abstract}
The introduction of a d.c. bias current to an r.f. glow-discharge plasma led to an intensity increase of particular emission lines. It was considered that the excitation mechanism was investigated based on Boltzmann plots of chromium emission lines with and without the introduction of a bias current. In the case of $\mathrm{Cr}$ I lines, the Boltzmann plot follows a straight lines without bias-current introduction, whereas it bends upwards when a bias current is introduced. This effect could be explained from the fact that the excited levels having energies of $4.2 \mathrm{eV}$ and $5.8 \mathrm{eV}$ were more populated compared to the excited levels of $3.3 \mathrm{eV}$ through collisions with introduced electrons. On the other hand, the Boltzmann plot of $\mathrm{Cr}$ II lines bends downwards with no bias currents, which is caused by the selective excitation of $\mathrm{Cr}$ ion species having excitation energies of $8 \mathrm{eV}$ through charge-transfer collisions between $\mathrm{Cr}$ atoms and $\mathrm{Ar}$ ions. When bias currents were introduced, the charge transfer collisions could be less effective, leading to a straight-line relationship of the Boltzmann plot of the Cr II lines. These results effects suggest that introducing a bias current is effective to enhance the intensities of not only the $\mathrm{Ni}$ or $\mathrm{Cr}$ atomic emission lines, but also the other atomic-emission lines.
\end{abstract}

Keywords : r.f. glow-discharge plasma; Grimm glow lamp; enhancement of emission intensity; Boltzmann plot; chromium.

\section{1 緒言}

グロー放電発光分光法 (glow discharge optical emission spectrometry：GD-OES）は，固体試料の直接分析を行う ことができる分析法である，特に，電源部に高周波電源を 用いた高周波グロー放電発光分光法 (r.f. GD-OES) では, 導電性の試料のみならず絶縁物を含めた様々な試料の分析 を行うことができる.

高周波電源を放電管に接続すると，プラズマ内に直流成 分の自己バイアス電圧が発生することが知られている ${ }^{1)}$.

\footnotetext{
若手研究者の初論文特集

${ }^{1}$ 東北大学金属材料研究所: 980-8577 宮城県仙台市青葉区片平 2-1-1
}

通常，この自己バイアス電圧に起因する電流は，回路全体 のインピーダンスが大きいため流れない．しかしながら， 放電管にローパスフィルター回路を接続することで直流バ イアス電圧を高周波回路から分離し，外部回路により制御 することができる。すなわち，ローパスフィルター回路に 抵抗を接続すると，プラズマを含む回路全体にバイアス電 圧に起因する電流を流すことができる2 ${ }^{2}$ 。この直流バイア ス電圧に起因する電流をバイアス電流と呼んでいる2 の際, バイアス電流は中空電極から試料電極方向へと流れ るため, 電子は電流の流れとは逆方向の中空電極からプラ ズマへ導入される。これによってプラズマの特性が大きく 変わり, 比較的励起エネルギーが低い原子線の発光強度が 増大する ${ }^{2) 31}$. 


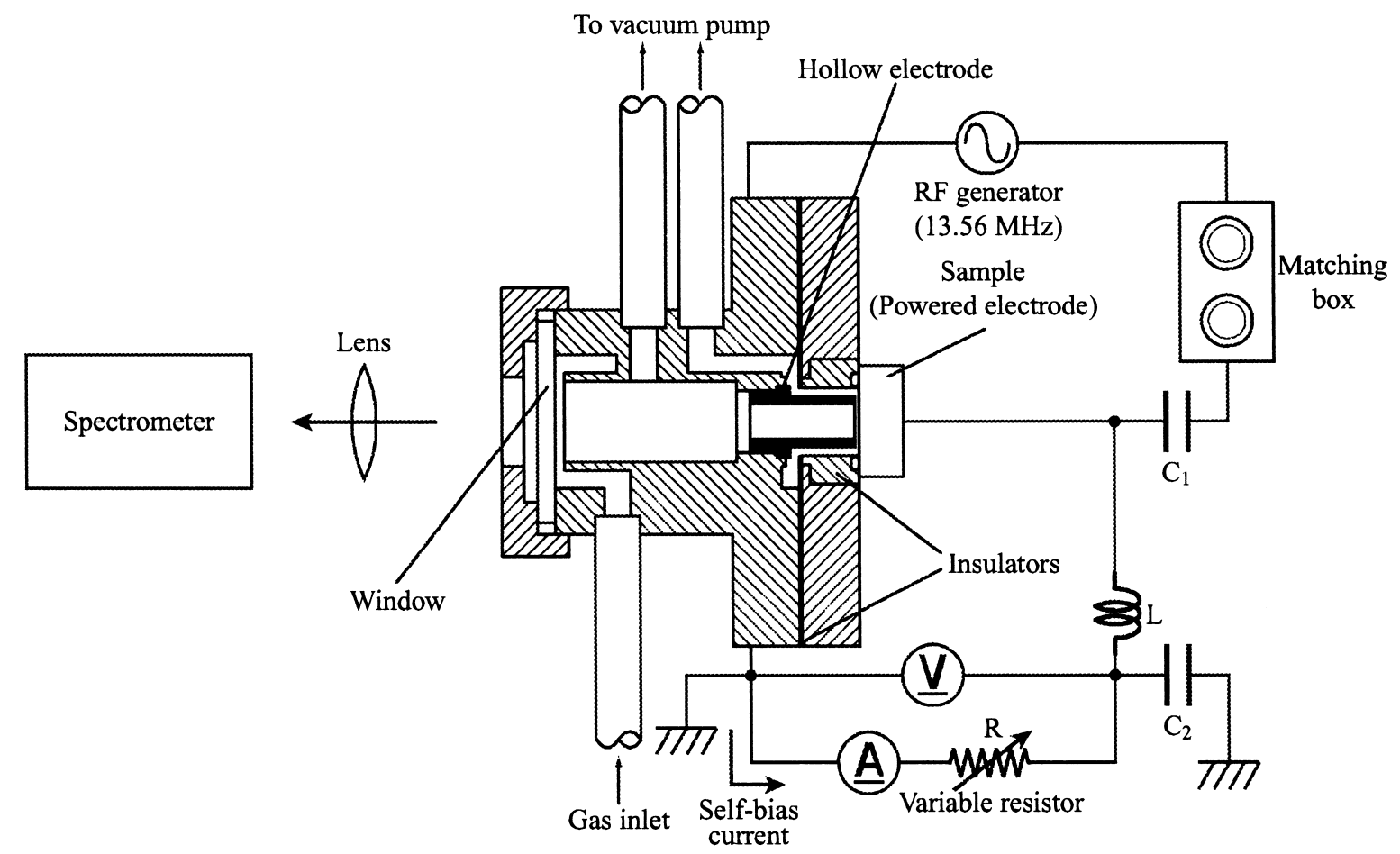

Fig. 1 Schematic diagram of bias-current controlled r.f. glow discharge plasma excitation source

この現象を用いることで, r.f. GD-OES の検出下限が大 きく改善されるが ${ }^{3) \sim 5)}$, バイアス電流導入による励起機構 について十分に解明されていない。これまで，バイアス電 流導入による発光線強度の変化を $\mathrm{Ni}$ 及び Arについて測 定し，励起機構について検討・報告を行ってきた ${ }^{6)}$ 。本報 では, より詳細に励起機構の検討を行うために, 確度の高 い遷移確率が分かっている $\mathrm{Cr}$ の発光線を用いて Boltzmann Plot法によるプラズマ解析を試みたので, その結果 を報告する。

$$
2 \text { 実験 }
$$

\section{$2 \cdot 1$ 測定原理}

Fig. 1 に本研究に用いた装置の概略図を示す，グロー放 電管に高周波電源を接続すると放電管内にプラズマが生成 する。この際，プラズマ内での陽イオンと電子の移動度に 差があり，また試料がコンデンサーを介して電源と接続さ れているために，プラズマ内には直流成分の自己バイアス 電圧が誘起される ${ }^{1)}$.この結果, 試料は中空電極に対して 負の電位を持つ.プラズマガスイオンはこの自己バイアス 電圧により運動エネルギーを与えられ, 試料方向へと加速 され, 試料表面に衝突しスパッタリングが起こる. 自己バ イアス電圧に起因する直流電流は, 回路全体のインピーダ ンスが非常に大きいため, 通常は流れていない. しかしな がら Fig. 1 に示すように，コイル（L）とコンデンサー $\left(\mathrm{C}_{2}\right)$ からなるローパスフィルター回路を接続すると, 自
己バイアス電圧を高周波回路から分離して測定することが できる．更にローパスフィルター回路に抵抗（R）を接続 すると，プラズマをその一部とする直流閉回路が形成さ れ，バイアス電流が流れる。この際，自己バイアス電圧は バイアス電流を流すための電池の役割を果たしていると考 えることができる．可変抵抗の抵抗值を適切に調整する と,グロー放電の安定を損なうことなくプラズマ内にバイ アス電流を導入することができる.

バイアス電流は中空電極から試料方向へと流れ，それに 伴い中空電極からプラズマ内には多数の電子が導入され る.プラズマ内に導入された電子が試料原子と衝突・励起 することにより試料原子やプラズマガスからの発光強度の 変化をもたらしている。一部の発光線は顕著な強度の増感 が見受けられ，発光分析の高感度化に利用できる.

\section{$2 \cdot 2$ 装 置}

本研究で使用したグロー放電管は Grimm 型の基本構造 を持つもので7), 絶縁部分以外はすべて真鍮製である. 中 空電極の内径は $8 \mathrm{~mm}$, 試料と電極の間隔は約 $0.3 \mathrm{~mm}$ と なるように調整した。高周波電力は同軸ケーブルを用い て, 高周波電源（東京ハイパワー製 HL-2K）からマッチ ングボックス（クラニシ製 NT-303）を介して試料背面に 供給した，供給する電力は $100 \mathrm{~W}$ と固定し，反射電力が $1.0 \mathrm{~W}$ 以下になるようにマッチングボックスを調整した. ブロッキングコンデンサー $\left(\mathrm{C}_{1}\right)$ とローパスフィルター回 
Table 1 Atomic Chromium lines for the Boltzmann plot

\begin{tabular}{llcccc}
\hline Wava lenght/nm & \multicolumn{1}{c}{ Upper level } & Lov & Lower level & /eV & gA-value $\times 10^{89)}$ \\
\hline 373.081 & $3 d^{5}\left({ }^{6} \mathrm{~S}\right) 4 p^{5} \mathrm{P}_{2}$ & 3.3222 & $3 d^{5}\left({ }^{6} \mathrm{~S}\right) 4 s^{7} \mathrm{~S}_{3}$ & 0.0000 & 0.011 \\
373.203 & $3 d^{5}\left({ }^{6} \mathrm{~S}\right) 4 p^{5} \mathrm{P}_{3}$ & 3.3212 & $3 d^{5}\left({ }^{6} \mathrm{~S}\right) 4 s^{7} \mathrm{~S}_{3}$ & 0.0000 & 0.008 \\
374.389 & $3 d^{4}\left({ }^{3} \mathrm{H}\right) 4 s 4 p\left({ }^{3} \mathrm{P}\right)^{5} \mathrm{G}_{6}$ & 5.8547 & $3 d^{5}\left({ }^{4} \mathrm{G}\right) 4 s^{5} \mathrm{G}_{6}$ & 2.5440 & 9.839 \\
374.449 & $3 d^{4}\left({ }^{3} \mathrm{H}\right) 4 s 4 p\left({ }^{3} \mathrm{P}\right)^{5} \mathrm{G}_{6}$ & 5.8547 & $3 d^{5}\left({ }^{4} \mathrm{G}\right) 4 s^{5} \mathrm{G}_{5}$ & 2.5446 & 0.651 \\
374.717 & $3 d^{4}\left({ }^{3} \mathrm{H}\right) 4 s 4 p\left({ }^{3} \mathrm{P}\right)^{5} \mathrm{G}_{3}$ & 5.8427 & $3 d^{5}\left({ }^{4} \mathrm{G}\right) 4 s^{5} \mathrm{G}_{2}$ & 2.5438 & 0.431 \\
375.766 & $3 d^{4}\left({ }^{3} \mathrm{H}\right) 4 s 4 p\left({ }^{3} \mathrm{P}\right)^{5} \mathrm{G}_{3}$ & 5.8427 & $3 d^{5}\left({ }^{4} \mathrm{G}\right) 4 s^{5} \mathrm{G}_{3}$ & 2.5442 & 2.891 \\
375.804 & $3 d^{4}\left({ }^{3} \mathrm{H}\right) 4 s 4 p\left({ }^{3} \mathrm{P}\right)^{5} \mathrm{G}_{3}$ & 5.8427 & $3 d^{5}\left({ }^{4} \mathrm{G}\right) 4 s^{5} \mathrm{G}_{4}$ & 2.5446 & 0.812 \\
376.824 & $3 d^{4}\left({ }^{3} \mathrm{H}\right) 4 s 4 p\left({ }^{3} \mathrm{P}\right)^{5} \mathrm{G}_{3}$ & 5.8330 & $3 d^{5}\left({ }^{4} \mathrm{G}\right) 4 s^{5} \mathrm{G}_{2}$ & 2.5438 & 2.550 \\
376.873 & $3 d^{4}\left({ }^{3} \mathrm{H}\right) 4 s 4 p\left({ }^{3} \mathrm{P}\right)^{5} \mathrm{G}_{2}$ & 5.8330 & $3 d^{5}\left({ }^{4} \mathrm{G}\right) 4 s^{5} \mathrm{G}_{3}$ & 2.5442 & 0.595 \\
388.329 & $3 d^{4}\left({ }^{5} \mathrm{D}\right) 4 s 4 p\left({ }^{3} \mathrm{P}\right)^{5} \mathrm{D}_{3}$ & 4.1746 & $3 d^{4} 4 s^{25} \mathrm{D}_{2}$ & 0.9829 & 0.273 \\
388.522 & $3 d^{4}\left({ }^{5} \mathrm{D}\right) 4 s 4 p\left({ }^{3} \mathrm{P}\right)^{5} \mathrm{D}_{2}$ & 4.1586 & $3 d^{4} 4 s^{2} \mathrm{D}_{1}$ & 0.9684 & 0.195 \\
388.680 & $3 d^{4}\left({ }^{5} \mathrm{D}\right) 4 s 4 p\left({ }^{3} \mathrm{P}\right)^{5} \mathrm{D}_{4}$ & 4.1926 & $3 d^{4} 4 s^{25} \mathrm{D}_{3}$ & 1.0037 & 0.198 \\
389.404 & $3 d^{4}\left({ }^{5} \mathrm{D}\right) 4 s 4 p\left({ }^{3} \mathrm{P}\right)^{5} \mathrm{D}_{1}$ & 4.1439 & $3 d^{4} 4 s^{2}{ }^{5} \mathrm{D}_{0}$ & 0.9610 & 0.117 \\
390.291 & $3 d^{4}\left({ }^{5} \mathrm{D}\right) 4 s 4 p\left({ }^{3} \mathrm{P}\right){ }^{5} \mathrm{D}_{2}$ & 4.1586 & $3 d^{4} 4 s^{2} \mathrm{D}_{2}$ & 0.9829 & 0.175 \\
\hline
\end{tabular}

Table 2 Ionic Chromium lines for the Boltzmann plot

\begin{tabular}{|c|c|c|c|c|c|}
\hline Wava lenght/nm & Upper level & $/ \mathrm{eV}$ & Lower level & $/ \mathrm{eV}$ & gA-value $\times 10^{89)}$ \\
\hline 282.238 & $3 d^{4}\left({ }^{3} \mathrm{H}\right) 4 p^{4} \mathrm{I}_{15 / 2}$ & 8.1595 & $3 d^{4}\left({ }^{3} \mathrm{H}\right) 4 s^{4} \mathrm{H}_{13 / 2}$ & 3.7680 & 36.8 \\
\hline 284.001 & $3 d^{4}\left({ }^{3} \mathrm{H}\right) 4 p^{4} \mathrm{I}_{11 / 2}$ & 8.1108 & $3 d^{4}\left({ }^{3} \mathrm{H}\right) 4 s^{4} \mathrm{H}_{9 / 2}$ & 3.7466 & 32.4 \\
\hline 284.983 & $3 d^{4}\left({ }^{5} \mathrm{D}\right) 4 p^{6} \mathrm{~F}_{7 / 2}$ & 5.8553 & $3 d^{4}\left({ }^{5} \mathrm{D}\right) 4 s^{6} \mathrm{D}_{5 / 2}$ & 1.5061 & 7.36 \\
\hline 285.134 & $3 d^{4}\left({ }^{3} \mathrm{H}\right) 4 p^{4} \mathrm{I}_{9 / 2}$ & 8.0858 & $3 d^{4}\left({ }^{3} \mathrm{H}\right) 4 s^{6} \mathrm{H}_{7 / 2}$ & 3.7389 & 22.0 \\
\hline 285.677 & $3 d^{4}\left({ }^{5} \mathrm{D}\right) 4 p^{4} \mathrm{D}_{5 / 2}$ & 6.7726 & $3 d^{4}\left({ }^{5} \mathrm{D}\right) 4 s^{4} \mathrm{D}_{3 / 2}$ & 2.4339 & 2.58 \\
\hline 285.740 & $3 d^{4}\left({ }^{5} \mathrm{D}\right) 4 p^{4} \mathrm{D}_{7 / 2}$ & 6.7923 & $3 d^{4}\left({ }^{5} \mathrm{D}\right) 4 s^{4} \mathrm{D}_{5 / 2}$ & 2.4546 & 2.24 \\
\hline 286.092 & $3 d^{4}\left({ }^{5} \mathrm{D}\right) 4 p^{6} \mathrm{~F}_{3 / 2}$ & 5.8154 & $3 d^{4}\left({ }^{5} \mathrm{D}\right) 4 s^{6} \mathrm{D}_{1 / 2}$ & 1.4830 & 2.76 \\
\hline 286.258 & $3 d^{4}\left({ }^{5} \mathrm{D}\right) 4 p^{6} \mathrm{~F}_{7 / 2}$ & 5.8553 & $3 d^{4}\left({ }^{5} \mathrm{D}\right) 4 s^{6} \mathrm{D}_{7 / 2}$ & 1.5255 & 5.04 \\
\hline 286.672 & $3 d^{4}\left({ }^{5} \mathrm{D}\right) 4 p^{6} \mathrm{~F}_{3 / 2}$ & 5.8154 & $3 d^{4}\left({ }^{5} \mathrm{D}\right) 4 s^{6} \mathrm{D}_{3 / 2}$ & 1.4918 & 4.80 \\
\hline 286.709 & $3 d^{4}\left({ }^{5} \mathrm{D}\right) 4 p^{4} \mathrm{D}_{3 / 2}$ & 6.7569 & $3 d^{4}\left({ }^{5} \mathrm{D}\right) 4 s^{4} \mathrm{D}_{3 / 2}$ & 2.4339 & 4.40 \\
\hline 286.764 & $3 d^{4}\left({ }^{5} \mathrm{D}\right) 4 p^{6} \mathrm{~F}_{1 / 2}$ & 5.8052 & $3 d^{4}\left({ }^{5} \mathrm{D}\right) 4 s^{6} \mathrm{D}_{1 / 2}$ & 1.4830 & 2.20 \\
\hline 287.043 & $3 d^{4}\left({ }^{5} \mathrm{D}\right) 4 p^{4} \mathrm{D}_{5 / 2}$ & 6.7726 & $3 d^{4}\left({ }^{5} \mathrm{D}\right) 4 s^{4} \mathrm{D}_{5 / 2}$ & 2.4546 & 7.80 \\
\hline 287.381 & $3 d^{4}\left({ }^{5} \mathrm{D}\right) 4 p^{4} \mathrm{D}_{1 / 2}$ & 6.7468 & $3 d^{4}\left({ }^{5} \mathrm{D}\right) 4 s^{4} \mathrm{D}_{3 / 2}$ & 2.4339 & 1.76 \\
\hline
\end{tabular}

路（L， $\left.\mathrm{C}_{2}\right)$ を内蔵する, 研究室において作成した高周 波/直流分離器を試料に直接接続した. 今回作成したロー パスフィルター回路の遮断周波数は約 $400 \mathrm{kHz}$ であった。 バイアス電圧とバイアス電流の測定にはそれぞれデジタル 電圧計とデジタル電流計を用いた。可変抵抗の抵抗值は $2.2 \mathrm{k} \Omega$ から $76 \mathrm{k} \Omega$ まで 2.2 もしは $4.7 \mathrm{k} \Omega$ 刻みとした.

スペクトルの記録には走査型分光器（日立製作所製 $\mathrm{P}$ 5200 , 焦点距離 $750 \mathrm{~mm}$, 回折格子 3600 本 $/ \mathrm{mm}$ ）を用い た。各発光強度は 3 回測定し, その平均值をとった。測 定された強度の相対標準偏差（RSD）はおおむね $0.1 〜$ 3\%の範囲であり，最大でも $3.7 \%$ 以下であった。

\section{$2 \cdot 3$ 試 料}

試料には $\mathrm{Cr}$ 板（純度 $99.9 \%$ ）を用いた。プラズマガス には高純度 Ar ガス（純度 99.99995\%）を 4〜8 Torr（535

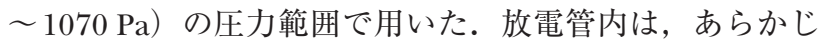
めオイルロータリーポンプを用いて $3 \times 10^{-2}$ Torr (4 Pa) 以下に保ち, 測定中はプラズマガスを常に放電管内に任意 の圧力で供給し続けた.プラズマガス圧はニードルバルブ
を用いて調整し，ピラニゲージを用いて圧力を測定した.

\section{3 結果と考察}

\section{$3 \cdot 1 \quad$ バイアス電流值とプラズマガス圧カの影響}

Tabel 1, Table 2 に今回測定した Crの原子線及びイオ ン線の帰属 ${ }^{8)}$ 並びに遷移確率 $(\mathrm{gA})^{9)}$ を示す。原子線及び イオン線において励起エネルギーのほぼ等しいグループの 中から 1 本ずつ, 計 6 本を代表的な発光線として選び, プラズマガス圧とバイアス電流值が発光強度の変化に与え る影響を調べた。原子線とイオン線のバイアス電流導入に よる強度変化を，それぞれ Fig. 2 及びFig. 3 に示す。こ こで Cr I はクロムの原子線を, Cr II はクロムのイオン線 を意味する．励起エネルギーが異なると，バイアス電流導 入による発光強度の変化には大きな違いが見られた。プラ ズマガス圧が 4 Torr の場合全般に強度の増大は認められ るが, 原子線では励起エネルギーが $3.3 \mathrm{eV}$ の発光線は, その他の発光線と比べて発光強度の増大の割合は小さかっ た.イオン線では励起エネルギーの増大に伴い, 発光強度 の増感傾向は小さくなった．プラズマガス圧が 6 Torr 及 


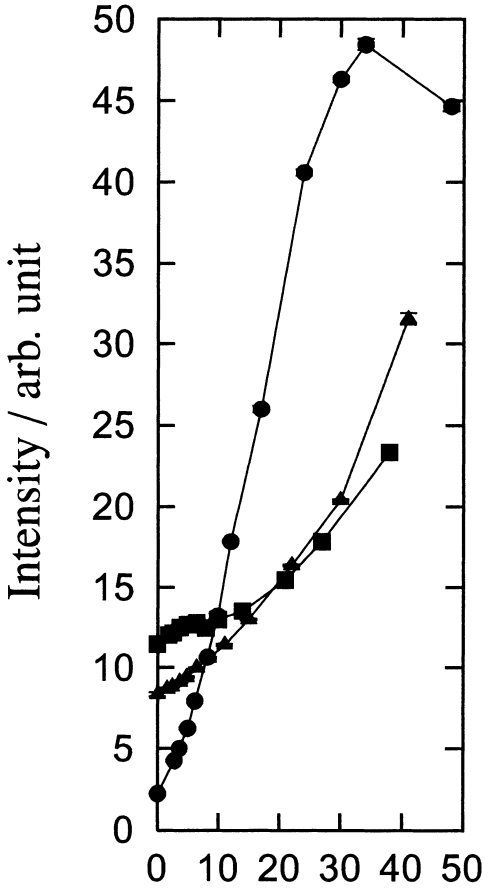

(a) $373.203 \mathrm{~nm}$

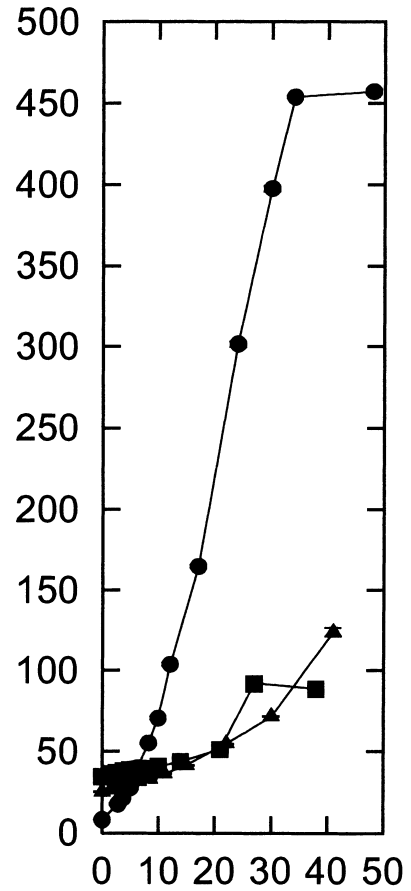

Bias current $/ \mathrm{mA}$

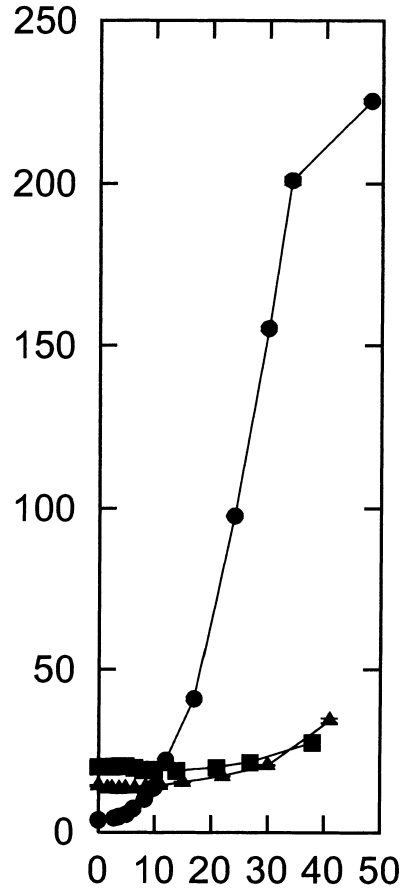

(c) $374.389 \mathrm{~nm}$

Fig. 2 Dependence of the emission intensities of (a) Cr I $373.203 \mathrm{~nm}$ (3.3212 eV), (b) Cr I 388.329 $\mathrm{nm}(4.1746 \mathrm{eV})$, and (c) Cr I $374.389 \mathrm{~nm}(5.8547 \mathrm{eV})$ on bias current at Ar pressure of 4 Torr $(\boldsymbol{O}), 6$ Torr $(\mathbf{\Delta})$, and 8 Torr (

び 8 Torr の場合では，原子線・イオン線ともに発光強度 の増大がほとんど認められなかった。

励起エネルギーの違いにより, 発光強度の変化が異なる というのは, Ni の発光線でも確認している ${ }^{6)}$. Fig. 2 に示 すような励起エネルギーが $5 \mathrm{eV}$ 程度の発光線の増感率が その他の発光線よりも高いという現象は, Ni の発光線に おける実験結果と一致する ${ }^{6)}$ 。このことからバイアス電流 導入による発光強度の増大は試料の種類によらず, 類似し た励起機構で起こっているものと考えられる. 中空電極か ら導入された電子による衝突が主要なメカニズムであると 推定され，この電子の運動エネルギーは中空電極部のシー ス電圧により決まりこの值は試料によらずほぼ一定であ $ろ^{1)}$. このため, 同等な励起エネルギーを持つ発光線は, バイアス電流導入に対して類似した挙動を示すものと考え られる。

イオン線の増感率は $\mathrm{Ni}$ の測定結果 ${ }^{6}$ とやや異なり，全 般的に増感率が $\mathrm{Ni}$ と比較して高くなっている。これは $\mathrm{Cr}$ と Ni のイオン化エネルギーの違いによるものと考えられ る. バイアス電流をプラズマ内に導入するとイオンと電子 の衝突による励起頻度は増加するが，同時にイオンと電子 の再結合頻度も増加する. その結果, イオン種の存在量が 相対的に低下するため，イオン線は同じ励起エネルギーの
原子線と比較して増感率が下がる傾向にある。 $\mathrm{Cr}$ 及び $\mathrm{Ni}$ の第一イオン化エネルギーはそれぞれ $6.7667 \mathrm{eV}, 7.6375$ $\mathrm{eV}$ と $\mathrm{Cr}$ のほうが約 $1 \mathrm{eV}$ 低い ${ }^{10)}$ ため, $\mathrm{Cr}$ は $\mathrm{Ni}$ と比べて イオン化が容易である。このため, $\mathrm{Ni}$ と比較して Cr イオ ンは中性原子になったとしても，導入した電子によってイ オン化する確率が高いと推測される。それ故に Cr のイオ ン線は Ni と比較して増感率が高くなると考えられる.

プラズマガス圧が 6 Torr 及び 8 Torr の場合, 発光強度 の増大がほとんど起こらなかった。プラズマガス圧が高い 場合では，Ar と導入された電子の衝突頻度が上がり，導 入された電子のプラズマ内での平均自由行程が短くなって いたためと考えられる.

\section{$3 \cdot 2$ Boltzmann Plot}

Cr の原子線及びイオン線を用いて Boltzmann Plot 法に より発光強度を解析し，プラズマガス圧を変化させた場合 及びバイアス電流の有無による場合について比較を行っ た.Fig. 4 及び Fig. 5 にその結果を示す。罒中の $I$ は各発 光線の発光強度を, $\lambda$ は発光線の波長を意味する. 直線は, 1 本の場合は全デー夕点に対する近似直線であり，2本の 場合は励起エネルギーの高い二つのデータグループ，励起 エネルギーの低いデータグループそれぞれに対する近似直 


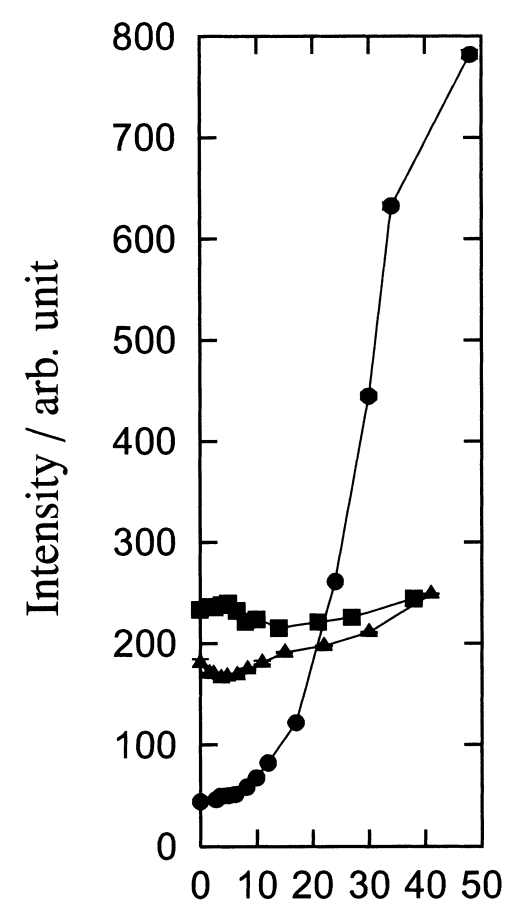

(a) $284.983 \mathrm{~nm}$

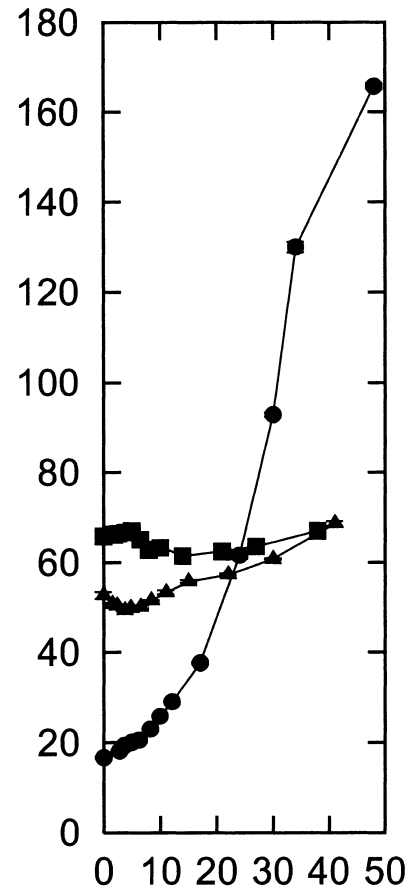

Bias current / $\mathrm{mA}$

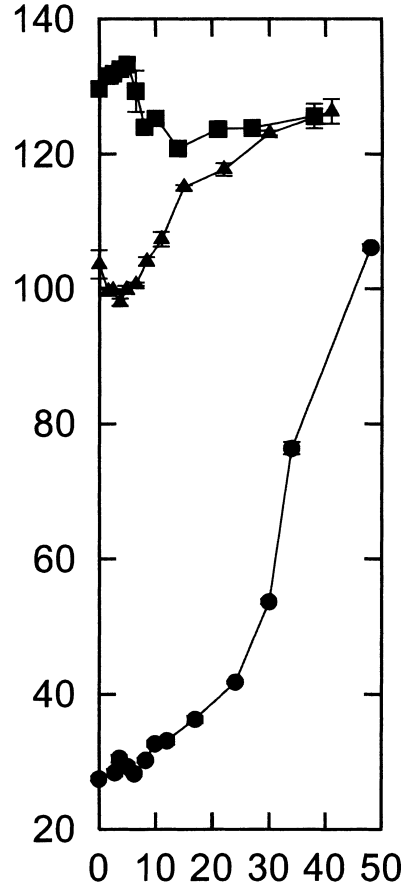

(c) $282.238 \mathrm{~nm}$

Fig. 3 Dependence of the emission intensities of (a) Cr II $284.983 \mathrm{~nm}(5.8553 \mathrm{eV}$ ), (b) Cr II 287.043 $\mathrm{nm}(6.7726 \mathrm{eV})$, and (c) Cr II $282.238 \mathrm{~nm}(8.1595 \mathrm{eV})$ on bias current at Ar pressure of 4 Torr $(\mathbf{O}), 6$ Torr $(\mathbf{\Delta})$, and 8 Torr

線である. 実線はバイアス電流を導入していないときの近 似直線, 点線はバイアス電流を導入したときの近似直線で ある。なお，近似直線は GNUPLOT MS-Windows 32 bit version 3.7 を用いて非線形の最小二乗アルゴリズムにより 決定した ${ }^{11)}$. Fig. 4 はプラズマガス圧を 4 Torr とした場 合の結果であるが，バイアス電流を導入しないときは直流 グロー放電の結果 ${ }^{12)}$ と同じ傾向を示す。すなわち, 原子線 の場合では良好な直線関倸を示すが，イオン線の場合では 下方向に折れ曲がっている。 これは励起エネルギーが 8 $\mathrm{eV}$ 以上の $\mathrm{Cr}$ のイオン線は他の発光線と異なり, 主要な励 起メカニズムが Cr 原子と $\mathrm{Ar}$ イオンの電荷移動衝突であ ると推定できるためである ${ }^{12)}$. しかしながら, バイアス電 流をプラズマ内に導入すると, Boltzmann plotの傾向は 大きく変わる，原子線では上方向に曲がり，イオン線では 直線関係に近くなっている.

バイアス電流を導入した場合, 励起エネルギーが $3.3 \mathrm{eV}$ の原子線は $4.2 \mathrm{eV}$ 及び $5.8 \mathrm{eV}$ の原子線と比べて増感率が 低い，すなわち $\mathrm{Cr}$ 原子の各励起準位間で数密度が相対的 に異なっていると考えられる. その結果 Boltzmann plot における直線関係は成立しなくなる。一方，イオン線の場 合は，電荷移動衝突に抄いてエネルギーを供与する Ar イ オンの相対密度がバイアス電流導入により低下し（再結
合 $)^{6)}$, 電荷移動衝突による $\mathrm{Cr}$ イオンの生成量が低下する と推定できる。そのため, Boltzmann plotは見かけ上直 線関倸に近づいたと考えられる.プラズマガス圧が 8 Torr の場合（Fig. 5)，バイアス電流を導入しても, Boltzmann plotの傾向は変わらなかった，前節でも述べたとおり，プ ラズマガス圧が高い場合バイアス電流を導入しても発光強 度に変化が見られない.このため Boltzmann plotの傾向 も変化しなかったと考えられる。

一般に, Boltzmann plotにおける直線相関は，プラズ マガスが局所熱平衡にあることを示すと考えられている が，上記のグロー放電プラズマではこれは必ずしも正しく ない.バイアス電流を導入したときの Cr イオン線のデー 夕のように, 非熱的プロセスの関与により Boltzmann plotが影響を受ける場合がある.

$$
4 \text { 結 論 }
$$

バイアス電流導入による発光強度の増大は, 新たにプラ ズマ内に導入された電子と試料原子の衝突により起こって いると考えられる。このとき電子の持つ運動エネルギー は，プラズマ本体と接地された中空電極の電位差によって 決定される。この電位差は試料電極には依存しないので, $\mathrm{Cr}$ を試料電極に用いた場合の新たに導入された電子の持 


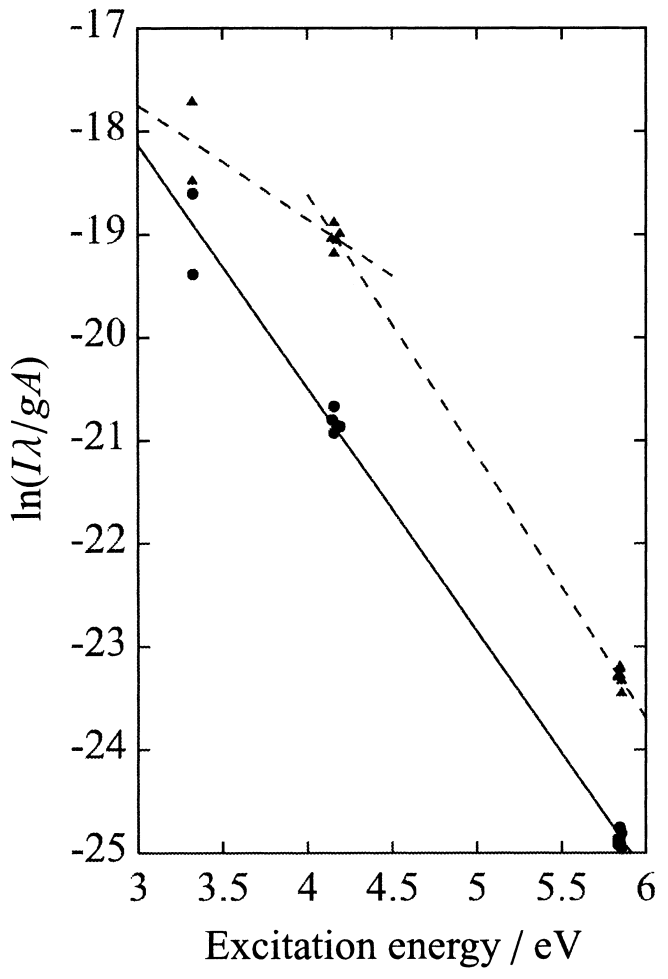

(a) Cr I lines

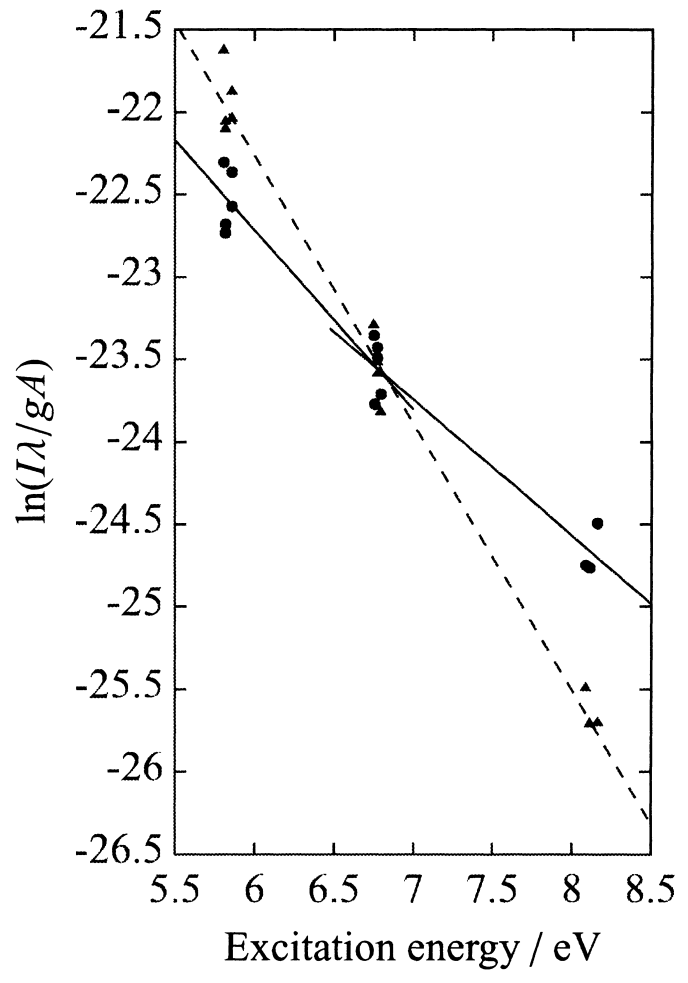

(b) $\mathrm{Cr}$ II lines

Fig. 4 Boltzmann plots of the Cr I lines (a) and the Cr II lines (b) at 4 Torr Ar No bias currents were introduced $(\mathcal{)})$ and bias current was introduced at $51 \mathrm{~mA}$

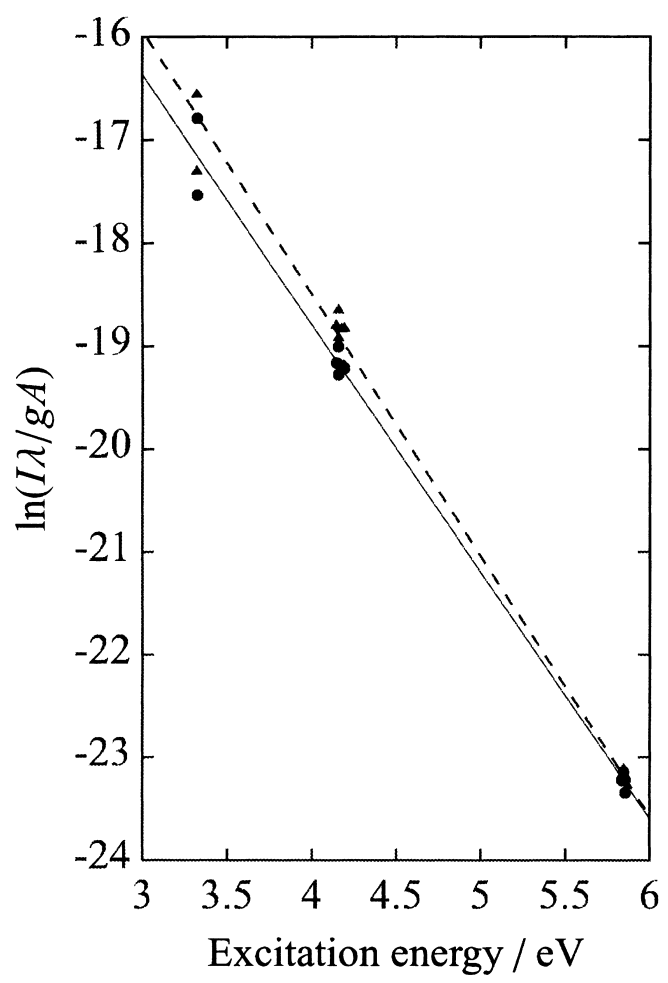

(a) Cr I lines

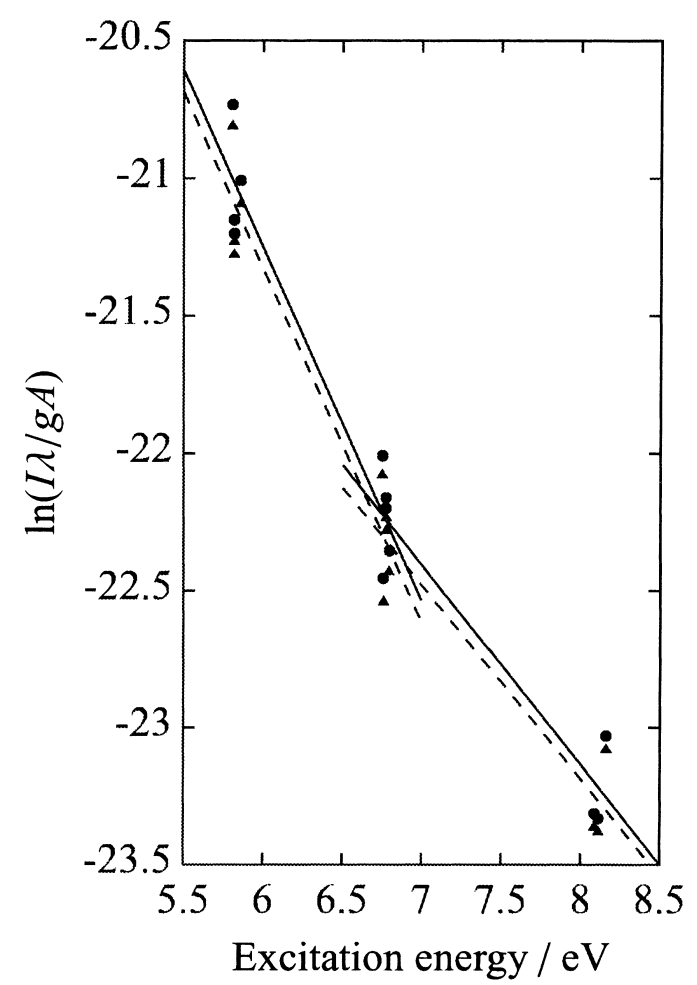

(b) Cr II lines

Fig. 5 Boltzmann plots of the Cr I lines (a) and the Cr II lines (b) at 8 Torr Ar No bias currents were introduced $(\mathbf{O})$ and bias current was introduced at $51 \mathrm{~mA}(\boldsymbol{\Delta})$ 
つ運動エネルギーは， $\mathrm{Ni}$ を試料電極に用いた場合と同様 であると考えられる.今回の実験結果は，原子線において 電子を新たに導入した際の励起機構は $\mathrm{Ni}$ の場合でも $\mathrm{Cr}$ の場合でも同様であり，その他の原子線についてもバイア ス電流導入法が有効であることを示唆している。

\section{文献}

1) B. N. Chapman: "Glow Discharge Processes", (1980), (J. Wiley \& Sons, New York).

2) K. Wagatsuma, H. Matsuta: Spectrochim. Acta, 54B, 527 (1999).

3) K. Wagatsuma: Spectrochim. Acta, 55B, 833 (2000).

4) 我妻和明: 鉄と鋼, 85, 34 (1999).
5) 我妻和明: 鉄と鋼, 88, 694 (2002).

6) K. Kodama, K. Wagatsuma: Spectrochim. Acta, 59B, 429 (2004).

7) W. Grimm: Spectrochim. Acta, 23B, 443 (1968).

8) C. E. Moore: “Atomic Energy Levels", (1952), (NBS Circular 467, Washington, DC).

9) G. A. Martin, J. R. Fuhr, W. L. Wiese: J. Phys. Chem. Ref. Data Suppl. No. 3, 17, 311 (1988).

10) J. Sugar, C. Corliss : J. Phys. Chem. Ref. Data Suppl. No. 2, 14, (1985).

11) 大竹 敢: “使いこなす GNUPLOT (改訂新版)”, p. 124 (2000), (テクノプレス).

12) K. Wagatsuma, Y. Danzaki, T. Nakahara: Spectroscopy Letters, 36, 99 (2003).

\section{要旨}

バイアス電流を高周波グロー放電プラズマに導入すると，プラズマの特性が変わり，各発光線の発光強度 が大きく変化する。このバイアス電流導入による励起機構について, Cr の発光線を用いた Boltzmann Plot 法による検討を行った．プラズマガス圧が 4 Torr の場合，バイアス電流導入の前後で Boltzmann Plot の傾 向は大きく異なった。これはバイアス電流導入によりプラズマ内に導入された電子がプラズマ電位により決 まる固有の運動エネルギーを持ち, Cr 原子の各励起準位の間に選択的励起が起こったためと, $\mathrm{Cr}$ 原子と $\mathrm{Ar}$ イオンとの間の電荷移動衝突に対してはバイアス電流導入法の効果が少なく，Cr イオンの励起準位間に数 密度の変化が起こるためと考えられる．バイアス電流導入による $\mathrm{Cr}$ の発光線強度の変化が， Ni の場合と同 様であったので, バイアス電流導入による発光強度の増大が様々な原子線に対して有効であると考えられる. 